\title{
Introducing the Analysis of Journal Articles
}

\author{
Josh Franco, Ph.D. \\ josue.franco@gcccd.edu \\ Political Science \\ Cuyamaca College \\ 900 Rancho San Diego Parkway \\ El Cajon, California 92019
}

Prepared for presentation at the American Political Science Association's 2020 Teaching and Learning Conference, February 7-9, 2020, Albuquerque, New Mexico 


\begin{abstract}
Peer-review journal articles are critical to knowledge creation and dissemination within any discipline, including political science. Additionally, journal articles represent dialogues between scholars in an academic community. The ability to critically read peer-reviewed journal articles is a skill that is developed with practice. And while this skill is essential for graduate students who are budding members of the community, it appears overlooked at the undergraduate level and especially in the community college setting. By not introducing the analysis of journal articles to this student population, we may be limiting their future success. Therefore, how can we introduce the analysis of journal articles to community college students and what effect does this have on their skills and interests? Utilizing a pre-test/post-test research design across five political science courses in a single semester at a community college, I examine how a Journal Article Analysis module, which is a collection of assignments and assessments, effects students' ability to analyze political science journal articles and their interest in the discipline.
\end{abstract}

Keywords: political science, pedagogy, journal article analysis 


\section{Introduction}

We live in the Information Age. Changes in society, the economy, and technology have been driving forces in bringing about and cementing this new age. The quantity and quality of information objects that we encounter every day is incredible: memes, bumper stickers, tweets, commercial signs, social media posts, blogs, newspaper articles, traffic signs, magazines, books, and the list goes on.

The preponderance of an information object is dependent on the setting. In academic settings, a staple of our information ecosystem are peer-reviewed journal articles (Tenopir, Mays, and Wu 2011). However, reading journal articles is different than reading a tweet or magazine. And we, as professors, can take for granted the knowledge, skill, and ability needed to read and analyze peer-reviewed journal articles.

In an increasingly fast-moving and complex world, there is a hunger for knowledge. We are aware that peer-review journal articles are critical to knowledge creation and dissemination within any discipline, including political science. And there is a clear understanding among college and university professors that journal articles represent dialogues between scholars in an academic community (Mabe 2010).

The ability to critically read peer-reviewed journal articles is a skill that is developed with practice. Each of us can trace back, with some reflection, our process for learning how to read and analyze journal articles. For some of us, as a professor at a four-year institution described the syllabus, we stared at this list of citations and wondered "What are these? And how am I ever going to read all this stuff?”

After the trials and tribulations of our undergraduate experience, we decide to partake in the grueling task of earning a graduate degree. And, now we know that part of earning additional degrees is being able to effectively and efficiently analyze journal articles. And while this skill is essential for graduate students who are budding members of the community, it can be less emphasized at the undergraduate level.

For one reason or another, it seems as if analyzing journal articles is not emphasized in community colleges. By not introducing the analysis of journal articles to this student population, we may be limiting their future success. Therefore, how can we introduce the analysis of political science journal articles to community college students and what effect does this have on their skills and interests?

Building on prior research (Franco 2019), I utilize a pre-test/post-test research design across seven political science courses in a single semester at a community college. I examine how a Journal Article Analysis module, which is a collection of assignments and assessments, effects students' ability to analyze political science journal articles and their interest in the discipline. 


\section{The Students}

It's safe to say that the reason we teach is because we care about our students. Introducing students to academic disciplines requires innovation, patience, and creativity. Given that teaching is our primary craft at the community colleges, we must strive to open the doors to the reservoirs of knowledge. And in doing so, we help students find their path going forward. It's an exciting proposition to be charged with, as opposed to burden by, leading the effort to opening the doors of higher education for millions of students.

During the fall 2019 semester, I taught approximately 165 students, across seven political science courses, in both face-to-face and online settings. Below is a table that shows the race or ethnicity of my students by gender. There are three observations we can draw from this table.

First, that the number of students who identify as female is greater than those who identify as male and non-binary. Secondly, we see that the largest racial and ethnic group are those who identify as Latino. Lastly, I would like to point out that we have a significant Middle Eastern population. Normally, this population is included in the White category, but students from this population have expressed the importance of being counted. Therefore, I include this category in

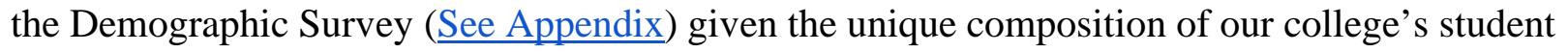
body.

Table \#\#\#. Race/Ethnicity by Gender

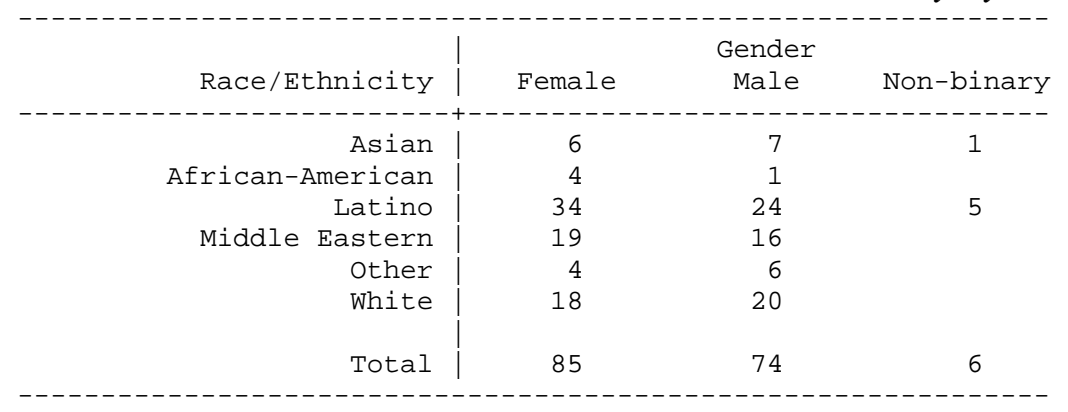

Community colleges, by definition, are open access institutions. This means that we get the entire range of students: the recent high school graduate, the single parent, the full-time worker, and the retired accountant. Community colleges are truly a melting pot because anyone, regardless of their education level or their experiences or their ability to pay, are welcomed to our institutions. First-generation college students are a population of interest at the community colleges (Inman and Mayes 1999; Pascarella et al. 2004). Our institutions pride themselves on institutionally and culturally serving this dynamic population. Considering this, below is another table that shows the race or ethnicity of students by first-generation college status and gender. The first thing I like to point out is that the number of first-generation college students is 88, which is greater than the 75 students who don't identify with this category. The second observation is that most first-generation students identify as female. Finally, a majority of students who identify as African-American, Other, or White are not first-generation college students. 


\begin{tabular}{|c|c|c|c|c|c|c|}
\hline Race & Female & $\begin{array}{c}1 s t \\
-\quad \text { No } \\
\text { Male }\end{array}$ & $\begin{array}{c}\text { ration Coll } \\
\text { Non-binary }\end{array}$ & $\begin{array}{l}\text { Student } \\
\text { Female }\end{array}$ & $\begin{array}{l}\text { nder } \\
\text { - Yes } \\
\text { Male }\end{array}$ & Non-binary \\
\hline Asian & 2 & 3 & & 4 & 4 & 1 \\
\hline African-American & 3 & & & 1 & & \\
\hline Latino & 10 & 6 & 1 & 23 & 18 & 4 \\
\hline Middle Eastern & 5 & 12 & & 14 & 4 & \\
\hline other & 3 & 5 & & 1 & 1 & \\
\hline White & 12 & 13 & & 6 & 7 & \\
\hline Total & 35 & 39 & 1 & 49 & 34 & 5 \\
\hline
\end{tabular}

Overall, what the two tables above demonstrate is that a diverse pool of students are enrolled in political science courses at my college.

\section{The Journal Article Analysis Module}

The fall 2019 semester started on August 19. The day before, students had access to the course website which contains the Journal Article Analysis (JAA) Module. The Module contains nine components. The first component is the pretest survey and all students were asked to complete it by September 1, which is one week prior to the due date for JAA \#1.

The second item is an Overview page. This page defines what journal articles are, briefly describes the peer review process and declares what analysis consist of. The next item is called the Anatomy of a Journal Article. This page reminds students what analysis consisted of as well as list the 12 typical parts of a political science journal article (See Appendix). In addition to the overall anatomy, a follow-up page described in greater detail each of the 12 parts (See Appendix). I would like to note that in my face-to-face classes, I walk through the overview and anatomy pages and leave the detailed page for students to read on their own.

The next three components of the module are Analyses \#1, \#2, and \#3. Each analysis explains what the assignment is about, provides an estimated time of 180 minutes to complete, offers instructions on downloading a PDF of the assigned article, links to both the anatomy and details pages, stating how to demonstrate identification of the 12 parts, and instructions on uploading the file to the course website. In the next section I will describe the specific articles that were assigned across my different political science courses. Additionally, a rubric is included that denotes how much each of the 12 parts is worth on a 100point total scale (See Appendix).

\section{JAA - Before Survey}

JAA - Overview

JAA - Anatomy of a Journal Article

JAA - Details of Analyzing Journal Articles

JAA - Analysis \#1 - September 8

JAA - Analysis \#2 - October 13

JAA - Analysis \#3 - November 17

JAA - My Reflection

JAA - After Survey

Figure \#\#\#: Visualization of Module 
The last two components are a reflection and the posttest survey. The reflection is an opportunity for the student to show me their thoughts about the Module. I asked students to ask themselves the question to answer it with at least five sentences. The idea is to allow the student to share with me what they think. Besides offering some example questions, I am open to reading what the student wants to share.

\section{Articles Assigned by Course}

At community colleges, political scientists are responsible for introducing students to the discipline. This means that we have the opportunity to offer students the range of introductory courses. Below is a table that includes the three journal articles assigned for each of the following courses: POSC 120 Introduction to Politics and Policy Analysis, POSC 121 Introduction to U.S. Government and Politics, POSC 140 Introduction to California Governments and Politics, POSC 124 Introduction to Comparative Politics, and POSC 130 Introduction to International Relations.

As you will notice, the cells containing the citations of the journal articles are color coded. Pink represents articles found in the journal Politics, Groups, and Identities. Blue represents articles found in the American Political Science Review. Green represents articles in the American Journal of Political Science. And yellow is an article from the Journal of Public Policy. Given the diverse student body of my community college, nine of the fifteen articles hail from Politics, Groups, and Identities. As an instructor, it is important for me to intentionally assign journal articles that are interesting, meaningful, and relevant to my students. I feel that Politics, Groups, and Identities' focus on "exploring the politics of gender, race, ethnicity, religion, sexuality, class and other dimensions of identity and structural disadvantage" meet this criterion.

Table \#\#\#. Journal Articles by Course

\begin{tabular}{|c|c|c|c|}
\hline Course & Journal 1 & Journal 2 & Journal 3 \\
\hline POSC & Heaney, Michael T. & Barberá, Pablo et al. & "Who Leads? Who \\
& 2019. & Formann, Nils-christian \\
et al. 2019. "Power \\
"Intersectionality at \\
the Grassroots." & Follows? Measuring & Issue Attention and & Behavior, and Peace." \\
& Politics, Groups, and & Agenda Setting by & American journal of \\
& Identities: 1-21. & Legislators and the Mass & political science 63(1): \\
& & Public Using Social & 84-100. \\
& & Media Data." The & \\
& & American political & \\
& & science review: $1-19$. & \\
\hline
\end{tabular}




\begin{tabular}{|c|c|c|c|}
\hline Course & Journal 1 & Journal 2 & Journal 3 \\
\hline $\begin{array}{c}\text { POSC } \\
121\end{array}$ & $\begin{array}{c}\text { Ditonto, Tessa. } 2019 . \\
\text { "Direct and Indirect } \\
\text { Effects of Prejudice: } \\
\text { Sexism, Information, } \\
\text { and Voting Behavior } \\
\text { in Political } \\
\text { Campaigns.” Politics, } \\
\text { Groups, and Identities: } \\
\text { 1-20. }\end{array}$ & $\begin{array}{l}\text { Thomsen, Danielle M. } \\
\text { 2019. “Which Women } \\
\text { Win? Partisan Changes in } \\
\text { Victory Patterns in US } \\
\text { House Elections.” } \\
\text { Politics, Groups, and } \\
\text { Identities 7(2): 412-28. }\end{array}$ & $\begin{array}{l}\text { Hero, Rodney E., Robert } \\
\text { R. Preuhs, and Olivia M. } \\
\text { Meeks. 2017. “Are These } \\
\text { Friends Also ‘friends of } \\
\text { the Court'?: Examining } \\
\text { Minority Legal } \\
\text { Advocacy Organization } \\
\text { Coalitions in Amicus } \\
\text { Brief Filings.” Politics, } \\
\text { Groups, and Identities: } \\
\text { 1-20. }\end{array}$ \\
\hline $\begin{array}{c}\text { POSC } \\
140\end{array}$ & $\begin{array}{l}\text { Marsh, Wayde Z. C., } \\
\text { and Ricardo Ramírez. } \\
\text { 2019. "Unlinking } \\
\text { Fate? Discrimination, } \\
\text { Group-Consciousness, } \\
\text { and Political } \\
\text { Participation among } \\
\text { Latinos and Whites." } \\
\text { Politics, Groups, and } \\
\text { Identities: 1-17.' }\end{array}$ & $\begin{array}{l}\text { Boudreau, Cheryl, } \\
\text { Christopher S. } \\
\text { Elmendorf, and Scott A. } \\
\text { MacKenzie. 2019. } \\
\text { "Racial or Spatial } \\
\text { Voting? The Effects of } \\
\text { Candidate Ethnicity and } \\
\text { Ethnic Group } \\
\text { Endorsements in Local } \\
\text { Elections.” American } \\
\text { journal of political } \\
\text { science 63(1): 5-20. }\end{array}$ & $\begin{array}{l}\text { Varone, F., K. Ingold, } \\
\text { and C. Jourdain. 2017. } \\
\text { "Defending the Status } \\
\text { Quo across Venues and } \\
\text { Coalitions: Evidence } \\
\text { from California Interest } \\
\text { Groups.” Journal of } \\
\text { public policy 37(1): 1- } \\
\text { 26. }\end{array}$ \\
\hline $\begin{array}{c}\text { POSC } \\
124\end{array}$ & $\begin{array}{l}\text { Gillooly, Shauna N. } \\
\text { 2019. “Indigenous } \\
\text { Social Movements and } \\
\text { Political } \\
\text { Institutionalization: A } \\
\text { Comparative Case } \\
\text { Study.” Politics, } \\
\text { Groups, and Identities: } \\
\text { 1-16. }\end{array}$ & $\begin{array}{l}\text { Levitt, Barry S. } 2015 . \\
\text { "Discrimination and the } \\
\text { Distrust of Democratic } \\
\text { Institutions in Latin } \\
\text { America.” Politics, } \\
\text { Groups, and Identities } \\
\text { 3(3): 417-37.' }\end{array}$ & $\begin{array}{l}\text { Moghadam, Valentine } \\
\text { M. 2018. “Explaining } \\
\text { Divergent Outcomes of } \\
\text { the Arab Spring: The } \\
\text { Significance of Gender } \\
\text { and Women’s } \\
\text { Mobilizations.” Politics, } \\
\text { Groups, and Identities } \\
\text { 6(4): 666-81. }\end{array}$ \\
\hline $\begin{array}{c}\text { POSC } \\
130\end{array}$ & $\begin{array}{c}\text { Caviedes, Alexander. } \\
\text { 2018. "European Press } \\
\text { Portrayals of } \\
\text { Migration: National or } \\
\text { Partisan Constructs?" } \\
\text { Politics, Groups, and } \\
\text { Identities 6(4): 802- } \\
\text { 13. }\end{array}$ & $\begin{array}{l}\text { Hangartner, Dominik et } \\
\text { al. 2019. “Does Exposure } \\
\text { to the Refugee Crisis } \\
\text { Make Natives More } \\
\text { Hostile?” The American } \\
\text { political science review } \\
\text { 113(2): } 442-55 .\end{array}$ & $\begin{array}{l}\text { Mattes, Michaela, and } \\
\text { Jessica L. P. Weeks. } \\
\text { 2019. "Hawks, Doves, } \\
\text { and Peace: An } \\
\text { Experimental Approach.” } \\
\text { American journal of } \\
\text { political science 63(1): } \\
\text { 53-66. }\end{array}$ \\
\hline
\end{tabular}




\section{Results from Pre-test and Post-test}

The Journal Article Analysis Pre-Test and Post-Test consists of a battery of five questions. The five questions asked the student four multiple choice questions and one matching question. See Appendix for the complete battery of questions. Question 4 asks: "How would you rate your ability to analyze political science scholarly journal articles on a scale from 1 (low) to 5 (high)?” I expect students to answer low before the course and high after the course. Therefore, my hypothesis is:

H\#: Students' ability to analyze political science scholarly journal articles will increase by the completion of the course.

The Journal Article Analysis accounted for 15\% of a students' overall grade. Each student was required to analyze three journal articles throughout the course of the semester. Each analysis required hand-annotating the 12 parts of a journal article and submitting for evaluation.

Figure \#\#\# is a kernel density plot which shows that most students rated themselves 3 or lower before the course, while we see that most students rated themselves 3 or higher after the course. Additionally, with a sample of 64 students the results of a Wilcoxon matched-pairs signed-ranks test allow me to reject the null hypothesis that the Module does not affect students' ability to analyze journal articles $(\mathrm{z}=4.7, \mathrm{p}=0.000)$.

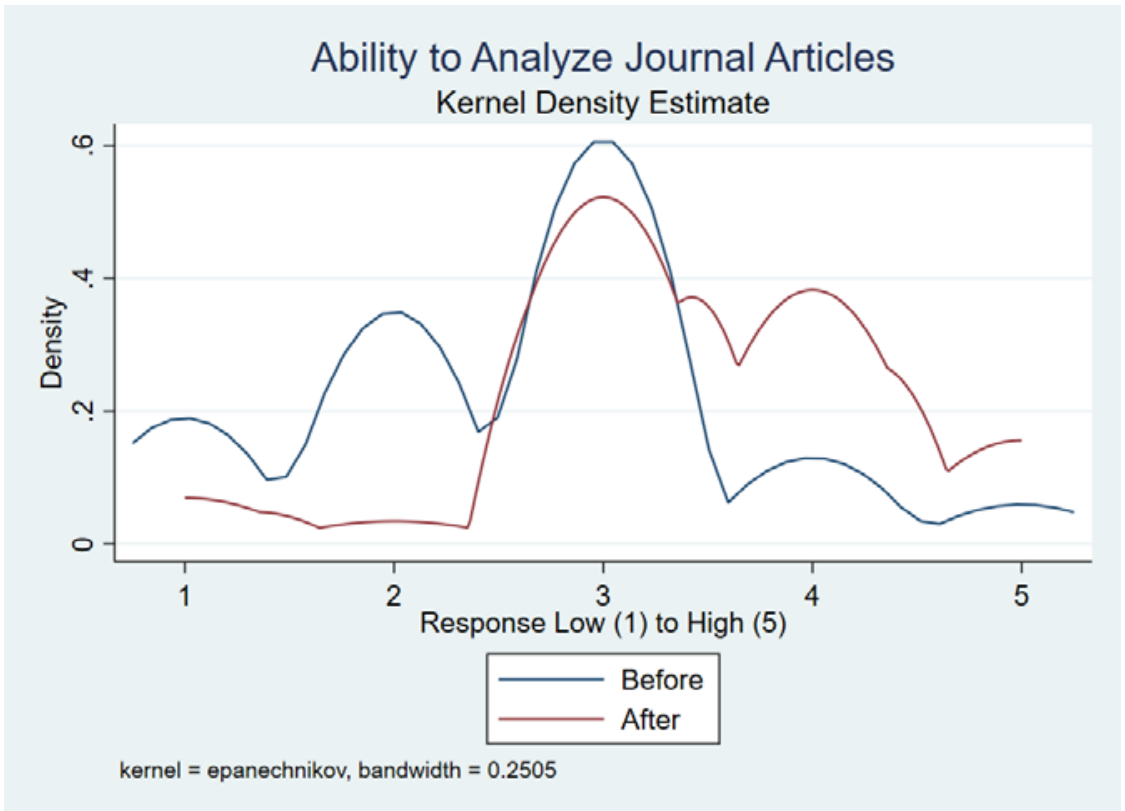

Figure \#\#\#. Ability to analyze journal articles

Recognizing that self-ratings are subjective (Boud and Falchikov 1989), how can be objectively measure students' ability to analyze journal articles? In both surveys, I asked students to match components of a journal article with their correct definition (See Question 5 in Appendix). Question 5 is independent of a specific journal article, so the intention of this question is not to 
ask about a specific article that was analyzed. Table \#\#\# shows detailed results for Question 5 before and after the module. The number of respondents in the pre-test is 136 while the number of respondents in the post-test is 68. I expect to see a positive percent change of correct responses from before to after. Overall, students show a positive percent change in correct responses for all ten terms.

Table \#\#\#. Results of Matching Question Before and After

\begin{tabular}{|c|c|c|c|c|c|c|c|}
\hline \multirow[b]{2}{*}{ Question } & \multicolumn{3}{|c|}{ Before } & \multicolumn{3}{|c|}{ After } & \multirow[b]{2}{*}{ \%Delta } \\
\hline & $\mathbf{R}$ & \# & $\%$ & $\mathbf{R}$ & \# & $\%$ & \\
\hline \multirow[t]{2}{*}{ Title } & 0 & 17 & $13 \%$ & 0 & 5 & $7 \%$ & $-5 \%$ \\
\hline & 1 & 119 & $88 \%$ & 1 & 63 & $93 \%$ & $5 \%$ \\
\hline \multirow[t]{2}{*}{ Main Point and Question } & 0 & 70 & $51 \%$ & 0 & 11 & $16 \%$ & $-35 \%$ \\
\hline & 1 & 66 & $49 \%$ & 1 & 57 & $84 \%$ & $35 \%$ \\
\hline \multirow{2}{*}{ Puzzle } & 0 & 56 & $41 \%$ & 0 & 8 & $12 \%$ & $-29 \%$ \\
\hline & 1 & 80 & $59 \%$ & 1 & 60 & $88 \%$ & $29 \%$ \\
\hline \multirow[t]{2}{*}{ Debate } & 0 & 43 & $32 \%$ & 0 & 11 & $16 \%$ & $-15 \%$ \\
\hline & 1 & 93 & $68 \%$ & 1 & 57 & $84 \%$ & $15 \%$ \\
\hline \multirow[t]{2}{*}{ Theory } & 0 & 68 & $50 \%$ & 0 & 10 & $15 \%$ & $-35 \%$ \\
\hline & 1 & 68 & $50 \%$ & 1 & 58 & $85 \%$ & $35 \%$ \\
\hline \multirow[t]{2}{*}{ Hypotheses } & 0 & 59 & $43 \%$ & 0 & 15 & $22 \%$ & $-21 \%$ \\
\hline & 1 & 77 & $57 \%$ & 1 & 53 & $78 \%$ & $21 \%$ \\
\hline \multirow[t]{2}{*}{ Research Design } & 0 & 83 & $61 \%$ & 0 & 16 & $24 \%$ & $-38 \%$ \\
\hline & 1 & 53 & $39 \%$ & 1 & 52 & $76 \%$ & $38 \%$ \\
\hline \multirow[t]{2}{*}{ Empirical Analysis } & 0 & 81 & $60 \%$ & 0 & 14 & $21 \%$ & $-39 \%$ \\
\hline & 1 & 55 & $40 \%$ & 1 & 54 & $79 \%$ & $39 \%$ \\
\hline \multirow[t]{2}{*}{ Policy Implications } & 0 & 72 & $53 \%$ & 0 & 21 & $31 \%$ & $-22 \%$ \\
\hline & 1 & 64 & $47 \%$ & 1 & 47 & $69 \%$ & $22 \%$ \\
\hline Contribution and Future & 0 & 71 & $52 \%$ & 0 & 23 & $34 \%$ & $-18 \%$ \\
\hline
\end{tabular}




\begin{tabular}{|l|c|c|c|c|c|c|c|}
\hline & \multicolumn{3}{|c|}{ Before } & \multicolumn{3}{c|}{ After } & \\
\hline Question & R & $\#$ & \% & R & $\#$ & \% & \%Delta \\
\hline Research & & & & & & & \\
\hline & 1 & 65 & $48 \%$ & 1 & 45 & $66 \%$ & $18 \%$ \\
\hline & \multicolumn{3}{|c|}{$\mathrm{n}=136$} & \multicolumn{3}{c|}{$\mathrm{n}=68$} & \\
\hline
\end{tabular}

\section{Conclusion}

While the employment of faculty at 2-year institutions is centered on teaching, counterpart faculty at 4-year universities are tasked with publishing peer-reviewed journal articles and books. Thus, a political scientist at a community college may be intensely focused on preparing lesson plans, reviewing teaching materials, and centered on the student learning experience. On the other hand, a political scientist at a 4-year university may be energetically centered on collecting data, writing manuscripts, and publishing. Obviously, this is not to say that the partition between faculty at different institutions is absolute, there are crossover faculty: researchers who care deeply about teaching, and teachers who care deeply about researching.

Acknowledging the incentives faculty have at their respective institutions, it is important to recognize the commonality, besides being a political scientist, and that commonality is our students. Our students bind us together at the range of institutions because they are the ones who will explore one and then traverse into another. Introducing the analysis of journal articles to community college students is important because it can better prepare them upon transferring to a 4-year university. From the research I conducted, I find that students demonstrate an increased competence in analyzing journal articles.

Clearly, students have the capacity to learn how to analyze research publications. This leads to a broader question of what does it mean to introduce a student in their first year at a college or university to peer-reviewed research? And more specifically, what does it mean to systematically walk that student through the process of analyzing journal articles in their first year as opposed to their third year of their undergraduate experience? How will the trajectory of the students change given that they have two more years of seeing, engaging with, and digesting peer-reviewed journal articles? 


\section{Appendix \#\#\#. Demographic Survey}

1. What's your age?

2. What's your gender?
a. Female
b. Male
c. Non-binary

3. What's your race or ethnicity?
a. American Indian or Alaskan Native
b. Asian
c. African-American
d. Latino
e. Middle Eastern
f. White
g. Other

4. What's your major?

5. Are you a 1st generation college student?
a. Yes
b. No

6. What is your current college GPA?
a. $3.7-4.0$
b. $3.5-3.69$
c. $3.0-3.49$
d. $2.5-2.99$
e. $0-2.49$
f. Not available

7. What best describes your plans after completing this course?
a. Get a job in local government
b. Get a job in state government
c. Get a job in federal government
d. Get a job in the private sector
e. Pursue an Associate's degree
f. Pursue a Bachelor's degree
g. Pursue a Master's degree
h. Pursue a Doctoral degree

8. What's your long-term academic goal?
a. Earn an Associate's degree
b. Earn a Bachelor's degree
c. Earn a Master's degree
d. Earn a Doctoral degree 
9. Which POSC courses have you successfully completed with a $\mathrm{C}$ or higher before this course?

a. POSC 120 Introduction to Politics and Political Analysis

b. POSC 121 Introduction to US Government and Politics

c. POSC 124 Introduction to Comparative Government and Politics

d. POSC 130 Introduction to International Relations

e. POSC 140 Introduction to California Governments and Politics

f. POSC 170 Introduction to Political Science Research Methods

g. This is my first POSC course

10. Which POSC courses are you taking or have you taken with Dr. Josh Franco?

a. POSC 120 Introduction to Politics and Political Analysis

b. POSC 121 Introduction to US Government and Politics

c. POSC 124 Introduction to Comparative Government and Politics

d. POSC 130 Introduction to International Relations

e. POSC 140 Introduction to California Governments and Politics

f. POSC 170 Introduction to Political Science Research Methods 


\section{Appendix \#\#\#. Journal Article Analysis Pre/Post Test Questions}

1. Which of the following best describes a journal article?
a. A blog post
b. A newspaper story
c. A publication
d. A peer-reviewed publication

2. How many journal articles have you read in your life time?
a. 0 so far
b. $1-10$
c. $11-20$
d. 21-30
e. $31-40$
f. $41-50$
g. $51-100$
h. $100+$

3. What percent of these journal articles have been in the field of political science?
a. $0 \%-32 \%$
b. $33 \%-49 \%$
c. $50 \%-66 \%$
d. $67 \%-100 \%$

4. How would you rate your ability to analyze political science scholarly journal articles on a scale from 1 (low) to 5 (high)?

5. Match the journal article component with its correct explanation

a. Title = appears on the first page of the article

b. Main Point and Question = are typically found in the Abstract

c. $\quad$ Puzzle $=$ a missing piece of knowledge that the article seeks to fulfill

d. Debate $=$ how scholars currently argue the subject of the article

e. $\quad$ Theory $=$ how the author thinks something works

f. Hypotheses $=$ are derived from the Theory

g. Research Design = how the author compares the effect of the explanatory variable $(\mathrm{X})$ on the outcome variable $(\mathrm{O})$ in a group $(\mathrm{G})$ or set of groups

h. Empirical Analysis = the use of quantitative or qualitative evidence to explore whether the hypothesized relationship between two variables does indeed occur in the world

i. Policy Implications = how the findings of the article should influence the behavior of individuals, groups, organizations, or governments

j. Contribution to the Discipline and Future Research = are how the article helps fill the missing Puzzle piece, as well as offer suggestions for future research that build on the findings from the article 


\section{Appendix \#\#\#. Typical Anatomy of a Journal Article in Political Science}

Journal Articles, especially in the field of political science, typically have twelve parts.

1. The Title of an article appears on the first page of the article. The Title is brief, typically no more than 5-10 words, and identifies for the reader the subject of the article.

2. The Main Point of an article is typically found in the Abstract. An Abstract is a summary of the article which is located on the first page, after the Title. The main point may be in the Introduction of the article.

3. The Question of an article is typically found in the Abstract. The question may be in the Introduction of the article as well.

4. The Puzzle is a missing piece of knowledge that the article seeks to fulfill.

5. The Debate is how scholars currently argue the subject of the article. Debates have at least two sides, and the two sides we are most familiar with are "pro" and "con". However, debates can be more complex.

6. The Theory is how the author thinks something works. For example, we may have a theory about how campaigns influence voters. Theories consists of constants, variables, and the relationships between variables.

7. The Hypotheses are derived from the Theory. A hypothesis is the expectation that one variable affects another variable in a specific way.

8. The Research Design is how the author compares the effect of the explanatory variable $(\mathrm{X})$ on the outcome variable $(\mathrm{O})$ in a group $(\mathrm{G})$ or set of groups.

9. The Empirical Analysis is the use of quantitative or qualitative evidence to explore whether the hypothesized relationship between two variables does indeed occur in the world.

10. The Policy Implications are how the findings of the article should influence the behavior of individuals, groups, organizations, or governments.

11. The Contribution to the Discipline is how the article helps fill the missing Puzzle piece

12. Future Research offers suggestions for future research that build on the findings from the article. 


\title{
Appendix \#\#\#. Details of Analyzing Journal Articles
}

\author{
12 Parts
}

Journal Articles, especially in the field of political science, typically have twelve parts.

\section{Title}

The Title of an article appears on the first page of the article. The Title is brief, typically no more than 5-10 words, and identifies for the reader the subject of the article.

- Titles are located at the top of the first page of a journal article

- Titles can be informative, as they may include the primary independent variable, primary dependent variable, or question of the article

\section{Main Point}

The Main Point of an article is typically found in the Abstract. An Abstract is a summary of the article which is located on the first page, after the Title. The main point may be in the Introduction of the article.

- Main points, while presented at the beginning of an article, are largely derived after the political scientist has completed their research. So, keep in mind that political scientists don't start with main points, typically, but rather the main point is a result of their research process

\section{Question}

The Question of an article is typically found in the Abstract. The question may be in the Introduction of the article, as well.

- An article can have more than one question. So, do not be surprised if you find more than one question. Keeping a list of questions is a useful way to eventually identify the primary question of the article, while also recognizing related secondary questions.

\section{Puzzle}

The Puzzle is a missing piece of knowledge that the article seeks to fulfill. 
- Puzzles are what political scientists try to solve. To solve a puzzle, a political scientist needs to have a sense of what the whole puzzle looks like. In other words, when you see the puzzle box and the image you are trying to recreate, that's a sense of the whole puzzle. Second, a political scientist needs to know how the current pieces fit together. Imagine that the puzzle was partially complete, so we would closely examine how the pieces that make up the partial puzzle are put together. Lastly, a political scientist decides which pieces they want to add to the partially complete portion of the puzzle. In other words, they need to decide which pieces they want to pick up and then try to it in place.

\section{Debate}

The Debate is how scholars currently argue the subject of the article. Debates have at least two sides, and the two sides we are most familiar with are "pro" and "con". However, debates can be more complex.

- Debates in political science can be normative or positive debates. Normative debates focus on "what should be" while positive debates focus on "what is." Most debates in political science are positive.

- Positive debates can exist on a conceptual, operational, or measurement level.

- Conceptual debates are were political scientists argue about a broad concept, like democracy or representation or power.

- Operational debates focus on taking broad concepts, like democracy, and arguing how they are represented in the real world. For example, many scholars would agree that the United States is conceptually a democracy. However, some scholars would argue and operationalize the United States as a representative democracy.

- Finally, measurement debates focus on how an operationalized concept is measured. For example, how do we measure a representative democracy? Are individuals elected to serve in national legislatures through winner-take-all a representative democracy? Or are individuals elected to serve in national legislatures through proportional representation a representative democracy?

\section{Theory}

The Theory is how the author thinks something works. For example, we may have a theory about how campaigns influence voters. Theories consists of constants, variables, and the relationships between variables.

- Theory is used by political scientists to clearly explain their logic of the constants, variables, and relationships between variables. 
- Constants are objects that do not change. A reason for stating constants is that the world is complex, therefore it is important to simplify it by "holding things constant." In other words, stating constants lets us focus on the variables and their relationship.

- Variables are objects that do change. Variables are typically classified into three categories: independent variable, mediating variable, and dependent variable. Independent variables are the objects that "cause" something to happen. Mediating variables are objects that "help cause" something to happen. And dependent variables are objects that are the "effect" of the "cause" and/or "helping cause."

- For example, your interpretation of a political actor, such as the President, may be caused by an action the President took. But your view of the action is mediated by your partisan affiliation.

\section{Hypotheses}

The Hypotheses are derived from the Theory. A hypothesis is the expectation that one variable effects another variable in a specific way.

- Above, I described a theory about how the action of a political actors effects your interpretation of the political actors, given your partisan affiliation. Now, we could generate several hypotheses from this theory.

- Hypothesis 1 is that if the President takes no action, then you will have no interpretation of the President

- Hypothesis 2 is that if the President acts, then you will have a positive view of the President if you have the same partisan affiliation as the President

- Hypothesis 3 is that if the President acts, then you will have a negative view of the President if you have a different partisan affiliation as the President.

\section{Research Design}

The Research Design is how the author compares the effect of the explanatory variable (X) on the outcome variable $(\mathrm{O})$ in a group $(\mathrm{G})$ or set of groups.

- Some political scientists use notation to denote research design. Below are 4 common examples, and 2 complex examples:

- Example 1: G O. This is a single group, observation only.

- Example 2: G X O. This is a single group, treatment then observation.

- Example 3: G O X O. This is a single group, observation before treatment, the treatment, then observation after treatment

- Example 4: G X O and G_O. This is a two-group design. Group 1 receives them treatment, then is observed. Group 2 does not receive the treatment, then observed. 
- Example 5: G O X O and G O _ O. This a two-group design. Group 1 and Group 2 are observed, then Group 1 receives the treatment while Group 2 does not receive the treatment. Finally, both Groups are observed again.

- Example 6: G O X O_ $\mathrm{O}_{\text {and }} \mathrm{G} \mathrm{O}_{-} \mathrm{O}$ X O. This is a two-group design, known as a switching replications design. Group 1 and Group 2 are observed, then Group 1 receives the treatment, while Group 2 does not receive the treatment. Then both Groups are observed. Next, Group 1 does not re-receive the treatment, and Group 2 receives the treatment for the first time. Then both groups are observed again.

\section{Empirical Analysis}

The Empirical Analysis is the use of quantitative or qualitative evidence to explore whether the hypothesized relationship between two variables does indeed occur in the world.

- Empirical analysis can feature quantitative, qualitative, or both types of evidence.

- Quantitative evidence includes data that is organized in a spreadsheet

- Political scientists using quantitative evidence conduct statistical analysis using statistical models to examine the data contained in their spreadsheet

- Qualitative evidence is typically individual or collection of text, images, and audio in a paper or electronic document

- Political scientists using qualitative evidence conduct content analysis or interpretation using non-theoretical or theoretical framework.

\section{Policy Implications}

The Policy Implications are how the findings of the article should influence the behavior of individuals, groups, organizations, or governments.

- Policy implications are typically stated by the political scientist towards the end of an article. What the researcher is doing is predicting how their article, and its findings, would influence the behavior of individuals, groups, organizations, or governments.

\section{Contribution to the Discipline}

The Contribution to the Discipline is how the article helps fill the missing Puzzle piece.

- Contribution to the Discipline is a statement of how the political scientists' research helps add a puzzle piece that was missing from our current world of knowledge. 


\section{Future Research}

Finally, Future Research is how the article offer suggestions for future research that build on the findings from the article.

- Future research are suggestions for what another political scientist can do to help build on this new knowledge that has been uncovered 


\section{Appendix \#\#\#. Rubric for Journal Article Analysis}

\begin{tabular}{|l|l|l|}
\hline Criteria & Ratings & Points \\
\hline Title Identified & Yes & 1 \\
\hline Main Point & No & 0 \\
\hline Question & Yes & 5 \\
\hline Puzzle Identified & No & 0 \\
\hline Hypotheses Identified & Yes & 5 \\
\hline Theory Identified & No & 0 \\
\hline & Yes & 10 \\
\hline & No & 0 \\
\hline & Yes & 10 \\
\hline & No & 0 \\
\hline & No & 10 \\
\hline & Nos & 0 \\
\hline & No & 10 \\
\hline & Yestified & 0 \\
\hline
\end{tabular}




\begin{tabular}{|c|c|c|}
\hline Criteria & Ratings & Points \\
\hline Empirical Analysis Identified & $\begin{array}{l}\text { Yes } \\
\text { No }\end{array}$ & $\begin{array}{l}10 \\
0\end{array}$ \\
\hline Policy Implications Identified & $\begin{array}{l}\text { Yes } \\
\text { No }\end{array}$ & $\begin{array}{l}5 \\
0\end{array}$ \\
\hline Contribution to the Discipline Identified & $\begin{array}{l}\text { Yes } \\
\text { No }\end{array}$ & $\begin{array}{l}5 \\
0\end{array}$ \\
\hline Future Research Identified & $\begin{array}{l}\text { Yes } \\
\text { No }\end{array}$ & $\begin{array}{l}5 \\
0\end{array}$ \\
\hline
\end{tabular}




\section{References}

Boud, David, and Nancy Falchikov. 1989. “Quantitative Studies of Student Self-Assessment in Higher Education: A Critical Analysis of Findings.” Higher Education 18 (5): 529-49.

Franco, Josh. 2019. “Integrating the 'Science' and 'Practice' of Politics in a Single Course: A Proof of Concept.” Journal of Political Science Education, March, 1-23. https://doi.org/10.1080/15512169.2019.1574587.

Inman, W. Elliot, and Larry Mayes. 1999. “The Importance of Being First: Unique Characteristics of First Generation Community College Students.” Community College Review 26 (4): 3-22. https://doi.org/10.1177/009155219902600402.

Mabe, Michael A. 2010. "Scholarly Communication: A Long View.” New Review of Academic Librarianship 16 (sup1): 132-44. https://doi.org/10.1080/13614533.2010.512242.

Pascarella, Ernest T., Christopher T. Pierson, Gregory C. Wolniak, and Patrick T. Terenzini. 2004. "First-Generation College Students: Additional Evidence on College Experiences and Outcomes.” The Journal of Higher Education 75 (3): 249-84.

https://www.tandfonline.com/doi/pdf/10.1080/00221546.2004.11772256?casa_token=v9ttL e5CoNgAAAAA:5b_9qisE0n8dPcoWLws9WI5ADsZWDA6pfPXzNe-3geZudokt4MgTsLx0N6BgObl3uihKmqkRoOyqw.

Tenopir, Carol, Regina Mays, and Lei Wu. 2011. "Journal Article Growth and Reading Patterns.” New Review of Information Networking 16 (1): 4-22.

https://doi.org/10.1080/13614576.2011.566796. 